\title{
A Comprehensive Study on Sinhala and English Verbs
}

\author{
A.B.I.K.Premasiri* \\ Sri Lanka Institute of Advanced Technological Education (SLIATE), Srilanka
}

*Corresponding Author: A.B.I.K.Premasiri, Sri Lanka Institute of Advanced Technological Education (SLIATE), Srilanka

\begin{abstract}
This study examines the similar and dissimilar aspects of Sinhala and English verbs. Sinhala is a diglossic language: having a separate written and spoken variety. In the study spoken or the colloquial Sinhala language has been used to make the comparison of the verbs of the two languages. In English much difference between the spoken and the written variety cannot be seen.
\end{abstract}

The research was carried out with the idea in mind that there should be some similarities of these two languages since both the two languages belong to the same language family: Indo- European. When started to research on the two languages it was found that studying about a language is a vast area of study. So, the area was narrowed down to the verbs of the Sinhala and English language.

Verbs of the two languages have been compared with the main focus on their voice, tense, aspect and mood. The data and findings under these four categories have been presented and analyzed. An introduction on various other types of verbal categories of the two languages has been presented for the reader to be aware of the basics of the verbs of Sinhala and English language.

At the end of the study it was found out that more than similar aspects of the verbs of the two languages there are more dissimilar aspects which are still helpful for the learners to have a deep insight into these languages.

A study of this kind on verbs is helpful for Sinhala learners whose second language is English as well as for Students learning Sinhala as a first or second language. It would be a guide for the teachers and for researchers who are interested in this field of study.

\section{INTRODUCTION}

Verb in a sentence is the important part of it. Sentences are put together around verbs. In other words, verbs are central to the construction of sentences. Verbs determine the other components in sentences and define the relationships among those components. Verbs tell us certain noun phrases function as subjects and that others functions as objects or as complements. So, studying about verbs correctly of a language is very important.

In Sri Lanka most of the people are bilinguals. Majority of them are Sinhala and the minority speak Tamil and some other languages. All of these people use English as a Second language except Burgher and Malay since their mother tongue is English. So, among the majority of Sinhala people, most of the people use Sinhala as their mother tongue and English as their second language.

Though English is the mother tongue of the Sinhalese only less number of them master the language and others are weaker in using it efficiently. They either do not use the language or use it wrong in social situations as well as in Education. So, many teachers and researchers want to find an easy way to teach English as a second language for the learners. With the idea of finding easier way to teach English some studies were carried out for a period of time .But none of the findings were kept in documents properly and when the necessity arose for a research to be done the idea came to do a research on Sinhala and English Language. As a result this study was carried out and finally only verbal categories of the two languages were selected to make the study easier and clear.

As learners of Sinhala and English languages we all know that there is no similarity of the verbs of the two languages apparently. So, we do not see any similarity between the verbs of the two languages as learners. But the researcher had the idea that when a deep study on the verbs of Sinhala and English languages are done the researcher would be able to find out some similar and dissimilar aspects. 
Here reference to some good books on verbs in Sinhala and English languages was done to study further and also to take examples to prove some differences and similarities. Hopefully, the research would help most of the students who have problems of similarities and differences of verbs in Sinhala and English language. This will help them to understand the similarities and variations which hinder them to master their second language (English) in writing, speaking and reading.

\section{Methodology}

This comparative study will be mainly based on lot of reading and my knowledge about the two languages and few on field work. Reading and studying books on verbs of English and Sinhala verbs will be the better and the easiest way to find necessary correct details. Since there are lot of reading involved, books, articles magazines, research studies etc. will be used as the primary materials for this study.

\section{LITERATURE REVIEW}

The book "Sinhala" by James W Gair and John Paolillo gives a deeper understanding to Sinhala verbs. "Sinhala is an Indo Aryan language spoken in Sri Lanka, where it has...non-verb predicates do not use a copula verb and fail to participate in subordination constructions that employ special verbal morphology. They discussed the deeper levels of the Sinhala language including the verbs."

Sinhala is a strongly diglossic language; (Gair and Paolillo).It has separate spoken and written two varieties. In "Sinhala" they have focused their attention on Spoken variety of the Sinhala language which is also the main focus of mine. "Spoken Sinhala being used for everyday purposes and Literary Sinhala for most written or scripted forms of communication. Available descriptions of Sinhala tend to address Literary Sinhala primarily". Literary Sinhala is acquired only through formal education and spoken variety in the Sri Lankan context is a naturalistic acquisition. (J.W.Gair 1968) In Sinhala there is distinctive diglossia, as in many languages of South Asia. The literary language and the spoken language differ from each other in many aspects. The written language is used for all forms of literary texts but also orally at formal occasions (public speeches, TV and radio news broadcasts, etc.), whereas the spoken language is used as the language of communication in everyday life. The most important difference between the two varieties is the lack of inflected verb forms in the spoken language.

"Sinhala is one of the official languages of Sri Lanka and the mother tongue of over $70 \%$ of the population.... Although the earliest surviving literature in Sinhala dates from the 8th century A.D., its written tradition has traced a longer path of more than 2,000 years." (DileepChandralal ).A deep insight to Sinhala language is given in the book "Sinhala" by DileepChandralal. His book presents the writing system, phonology, morphology, grammatical constructions and discourse and pragmatic aspects of Sinhala.

The book "Studies in South Asian Linguistics, Sinhala and other languages" by James W. Gair and Babara Lust is a collection of the twenty nine unpublished papers by the well famous linguist James W. Gair. He has done lot of research on Sri Lankan languages Sinhala and Jaffna Tamil and other Indian languages. This collection was an important resource for finding more details about Sinhala. A simple and comprehensive understanding can be taken from "An introduction to spoken sinhala" by W.S.Karunathilake and "A grammar of the Sinhala language" by Wilhelm Geiger.

In contrast English language is an Indo European language from the West Germanic branch and it is the official language of United Kingdom and United States. It is a link language used by most of the other countries in the world.

Some other books and articles helpful for my study were "English word formation" by Laurie Bauer and "Studies in English language" by M.A.K. Halliday, Jonathan J. Webster - 2009."The Oxford Reference Guide to English Morphology" by Laurie Bauer, Rochelle Lieber and Ingo Plag were very interesting.

Reference to some of the online site on English verb formation was done.

http://www.historyworld.net/wrldhis/PlainTextHistories.asp?historyid=ab13

http://www.thesundayleader.lk/2010/05/09/sri-lankan-english-the-state-of-the-debate/

http://homes.chass.utoronto.ca/ cpercy/courses/eng6365-saunders.htm

International Journal on Studies in English Language and Literature (IJSELL) 


\section{Sinhala AND ENGLiSh VerbS}

\subsection{What is verb?}

A verb is a member of the syntactic class of words that,

Typically signal events and actions,

Constitute, singly or in a phrase, a minimal predicate in a clause

Govern the number and types of other constitute which may occur in the clause.

In many languages, verbs are inflected to encode tense, aspect, mood, and voice. A verb may also agree with the person, gender, and/or number of some of its arguments, such as its subject, or object. Verbs have tenses: present, to indicate that an action is being carried out; past, to indicate that an action has been done; future, to indicate that an action will be done.

Verbs are used to indicate the actions, processes, conditions, or states of beings of people or things.

Verbs play an integral role to the structure of a sentence. They constitute the root of the predicate, which, along with the subject (the "doer" of the verb's action), forms a full clause or sentence-we cannot have a sentence without a verb. When we discuss verbs' role in the predicate, we usually divide them into two fundamental categories: finite and non-finite verbs.

\subsection{Tense of Sinhala and English verbs}

\subsubsection{Sinhala verbs}

In Sinhala verbs are inflected for tense, they are past and non-past tense. Sinhala has only two tenses as non-past and past. There is no marker for future tense in Sinhala and it is indicated by using words like heta 'tomarrow', hawasa 'evening', labanasatiye 'next week'

They are identified morphologically by the final -nəwa in the non-past indicative form.

Ex; bo-nəwa $=$ drink

Ka-nəwa =eat

Duwa-nəwa $=$ run

Bala-nəwa $=$ look

Sinhala verbs consists of a stem such as bo-'drink' ka-'eat' duwa-'run' and bala 'look'and some inflectional suffixes such as -nə- (non-past) and -wa (indicative form)

Mainly the termination of the verb root is considered to be responsible for classification of verbs. A root consist of non-past stem is used for present and future tenses and a past stem is used for past tenses. The non-past indicative form is considered as the citation form. Such stem vowels are also called Thematic vowels (Gair 1970). Apart from these three types which are all regular verbs the other major type of Sinhala verbs is irregular verbs.

When we consider the stem shape of Sinhala regular verbs, three types of Sinhala verbs can be identified. They are,

-ə- ending stems

-i-ending stems

-e- ending stems

Class 1 (-ə- ending stems)

This verb class has the widest range of verbs in the lexicon, both transitive and intransitive.

Stems of two syllables

Balə-nəwa 'look'

Andə-nəwa 'cry'

Pani-nəwa 'jump'

Gaya-nəwa 'sing' 
When making the past tense past tense, past tense suffix $-\mathrm{u}$ is added by removing the stem vowel $-\partial$ in the stem.

Non past

past tense

Balə-nəwa 'look'

bæluwa

Duwa-nəwa 'run'

diuwa

Gotanəwa 'weave'

getuwa

Dinə-nəwa

dinuwa

Stems of three syllables

Pupurə-nəwa 'split

Osawa-nəwa 'lift'

Sarəsa-nəwa 'decorate'

Past tense of three syllable stems

Non-past

Osawa-nəwa 'lift'

Sarəsa-nəwa 'decorate'

Uturuwa-nəwa 'boil'

\section{Past tense}

eseuwa

særasuwa

itireuwa

Class 2(-i- ending stems)

Verbs of this class can be either transitive or intransitive.

Adi-nəwa 'draw'

Bani-nəwa 'scold'

Ani-nəwa 'stick'

Then we will have a look at different sub classes of making past tense in this category.

Non-past

past

Sub-class 1 andi-nəwa 'wear'

ænda

Padi-nəwa 'paddle'

pædda

Sub-class 2 bani-nəwa 'scold'

bænna

Ari-nəwa 'open'

æria

Sub-class 3 bandi-nəwa 'marry'

bænda

Imbi-nəwa 'kiss'

imba

Sub-class 4

$$
\text { paradi-nəwa 'be defeated' }
$$

pærəduna

Waradi-nəwa 'be mistaken'

wæraduna

Class 3(-e- ending stems)

The specific feature of the verbs in this category are verbs are intransitive.

Ere- nəwa 'sink in'

Igile-nəwa 'fly'

Ide-nəwa 'ripen'

Past tense of this verb category can be identified as,

Non-past

past

Pipe-nəwa 'bloom'

pipuna

Mere-nəwa 'die'

meruna

Parawe-nəwa 'wither'

parauna 
Irregular verbs in Sinhala

Ya-nəwa 'go'

Bo-nəwa 'drink'

Kərə-nəwa 'do'

Ka-nəwa 'eat'

e-nəwa 'come'

de-nəwa 'give'

Past tense of the above irregular Sinhala verbs can be identified as follows,

$\begin{array}{lc}\text { Non-past } & \text { past } \\ \text { Ya-nəwa 'go' } & \text { giaa } \\ \text { Bo-nəwa 'drink' } & \text { biiwa } \\ \text { Kərə-nəwa 'do' } & \text { kəlaa } \\ \text { Ka-nəwa 'eat' } & \text { kææwa } \\ \text { e-nəwa 'come' } & \text { aawa } \\ \text { de-nəwa 'give' } & \text { dunna }\end{array}$

\subsubsection{English verb}

A verb must agree with its Subject in Number and Person. When we use a verb, we have to say who or what is doing the action. This 'who or what' is the subject of the verb. The subject and the verb agree when they match each other.

Singular Verb

Use a singular verb if the subject is a singular noun.

e.g.

John goes to office

She eats a mango

The poet composes poetry

They build a temple

This form of the verb is called the third person singular. You use it when the subject of the verb is not you or the person you are speaking to, but some other person - a third person - or a thing. The third person singular verbs that end in 's'

e.g.

Runs Waits Goes Rings

e.g.

My uncle and guardian has come

Mom and Dad love us

$\underline{\text { Plural Verb }}$

Use a plural verb if the subject is a plural noun. Do not add s, es or ies to plural verbs. Plural verbs are also used with the pronouns I, we, you and they.

e.g.

My brothers listen to music a lot

The stars shine brightly on a clear night

I listen to music a lot 
You eat well

They build a temple

We drink tea on every day

Some children learn very fast

Some people drink coffee

The Verb gives us what people, animals or things are doing. It has six basic verb forms

\section{The Six Basic Verb Forms}

e.g.

\begin{tabular}{|c|c|c|}
\hline Base Form & walk & go \\
\hline Present & walk / walks & go / goes \\
\hline Past & walked & went \\
\hline Infinitive & to walk & to go \\
\hline Present Participle & walking & going \\
\hline Past Participle & Walked & gone \\
\hline
\end{tabular}

There are only two tenses in English-past and present. If we want to indicate the present tense we may use the base form of the verb, whilst the past form ends with -ed and there is no separate inflection for the future and to indicate future we use either the present tense ( I am going to Kandy next week- this can also be seen in newspaper headlines and in narrative descriptions) or the modal auxiliary verbs shall and will in conjugation with the main verb(I shall go home tomorrow).Many linguists refer to the present tense using the term non-past since they believe that the term non-past more accurately expresses the use of the present tense as a means of referring to times other than the past.

We have two verb types in English; regular verbs and irregular verbs.

Regular verbs

Past tense of the regular verbs are made by adding -ed -to the verb stem. The base form of a verb in English is the infinitive without the preposition -to- functioning as an infinitive marker.

Non-past

past

Dance

danced

Talk

talked

Discuss

discussed

Collect

collected

Gain

gained

In English there are several ways of irregular verbs in past tense.

The verbs of a simple sentence

Verb is a core of every sentence. Without verb, a group of words is only a fragment of a sentence instead of a complete sentence. Even if a sentence contains only one word, that word must be a verb:

e.g.

Run! Wait! Go! Ring!

Every verb must have a subject, expressed or understood. The subject of a verb is to assert something about its subject that is, to tell what the subject does (did, will do) or that the subject is (was, will be) something.

Subject + verb

e.g.

Subject Verb

Horse eats 
This sentence consists of one clause. The clause has two parts, a Subject and a Verb. But this is not a complete sentence.

Subject + verb + object

e.g.

Subject Verb Object

Horse eats grass

The object of a clause is normally comes after the verb. This sentence is a complete sentence. The grass is clearly affected by the action of eating.

\subsection{Aspect in English and Sinhala}

\subsubsection{Aspect in English}

Aspect in English expresses progressive actions or states with or without distinct end points. The aspect of a verb is determined by whether the action is ongoing or completed. Aspect is the grammaticalized expression of the temporal structure of an action or state, which roughly relates to duration.

The four aspects are:

- Simple Aspect (also known as the indefinite aspect)

- Perfect Aspect (also known as the complete aspect)

- Progressive Aspect (also known as the continuing aspect)

- Perfect Progressive Aspect

Aspects of the present tense:

- Present simple (not progressive, not perfect): "I eat"

- Present progressive (progressive, not perfect): "I am eating"

- Present perfect (not progressive, perfect): "I have eaten"

- Present perfect progressive (progressive, perfect): "I have been eating"

Aspects of the past tense:

- Past simple (not progressive, not perfect): "I ate"

- Past progressive (progressive, not perfect): "I was eating"

- Past perfect (not progressive, perfect): "I had eaten"

- Past perfect progressive (progressive, perfect): "I had been eating

Aspects of the future tense.

- Simple future, simple conditional: "I will eat", "I would eat"

- Future progressive, conditional progressive:

"I will be eating", "I would be eating"

- Future perfect, conditional perfect: "I will have eaten", "I would have eaten"

- Future perfect progressive, conditional perfect progressive:

"I will have been eating", "I would have been eating"

\subsubsection{Aspects in Sinhala}

The simple present may also have a future or a progressive sense. In Colloquial Sinhalese it is the same as the infinitive, e.g. enavā ('come[s]/ coming/ will come').

The simple past is marked by a change in the verbal base, e.g. āvā ('came'). The stem of the verb 'to come' changes from e to $\bar{a} v$ to $æ v$ in different tenses. 
The future is marked by the suffix -nnam. It is only used in the first person, e.g. ennam ('I/we will come').

The continuous and habitual tenses are formed by a repetition of the conjunctive participle plus an auxiliary. The present continuous requires the auxiliary innavā e.g. katā kara

karainnavā ('am/is/are talking'). The past continuous requires the auxiliarieshitịā or unnā,

e.g.katā karakaraunnā ('was/were talking').

The past habitual uses hitịā as auxiliary and adds the aspect marker-t- to the conjunctive participle, e.g. æviævithițiyā ('used to come').

The perfect tenses are formed with the conjunctive participle marked by the suffix -lā plus an auxiliary. The present perfect uses the auxiliary tiyenavā (emphatic form tiyenne), e.g. ævillā tiyenavā ('has/have come'). There is also an unspecified perfect without tense marker that has a similar sense, e.g. ævillā ('has/have come '). The past perfect uses the auxiliary ti (b)unā, e.g.ævillā tibunā ('had come').

\subsection{Mood in English and Sinhala}

\subsubsection{Mood in English}

Mood is the expression of modality of an action or state. Modality is the expression of possibility, necessity, and contingency. Modality can be expressed through modal verbs as well as through grammatical mood in English.

English has four moods: indicative, subjunctive, and imperative and infinitive

The indicative mood allows speakers to express assertions, denials, and questions of actuality or strong probability. Most sentences in English are in the indicative mood because the indicative is the most commonly used mood.

For example, the statement I read the book and the question Did you read the book? are both sentences in the indicative mood.

The subjunctive mood expresses commands, requests, suggestions, wishes, hypotheses, purposes, doubts, and suppositions that are contrary to fact at the time of the utterance. The form of the present subjunctive is identical to the base form of English verbs. The form of the past subjunctive is identical to the plural simple past indicative. However, the subjunctive is only distinguishable in form from the indicative in the third person singular present subjunctive and with the verb to be in the present subjunctive and the first and third person singular in the past subjunctive.

The imperative mood allows speakers to make direct commands, express requests, and grant or deny permission. The form of the English imperative is identical to the base form of any English verb. The negative form of the English imperative is created by inserting the do operator and the negative adverb not before the base form of the verb.

Except those three moods in English, in the oxford Dictionary there is a reference to two other moods in English.(https://en.oxforddictionaries.com/grammar/moods)

The conditional mood

The conditional mood is made from the auxiliary verb would (also should with I and we) and the infinitive of the other verb without to. It's used to make requests and to refer to situations which are uncertain or which depend on something else happening or being the case:

I would like some coffee please.

If he'd arrived earlier, we would have had time for dinner.

We would live in Spain if we had the money.

The interrogative mood

This mood is used to ask questions. Interrogatives are formed by adding an auxiliary verb to another verb, with the auxiliary verb typically being placed before the subject:

Are you coming out tonight? 
When is she leaving?

Where have they gone?

Did you make a profit?

\subsubsection{Mood in Sinhala}

There are seven moods in Sinhala. They are, imperative mood, permissive mood, hortative mood, optative mood, conditional mood, inferential mood and exclamatory mood.

\section{a) Imperative Mood}

In imperative mood only the second person is involved .It is formed by adding the imperative suffux nno to the end of the verb root.

Class 1

balə+nnə =balənnə 'look'

kapa + nnə= kapannə 'cut'

class 2

adi + nnə $=$ adinnə 'pull'.

madi + nnə = madinnə 'iron'

class 3

pipe + nnə = pipennə 'bloom'

ride + nnə $=$ ridennə ' get pain'

class 4

e +nnə = ennə' come'

ya + nnə = yannə 'go'

some of the roots of the verb class4 (irregular verbs) have different forms for impolite imperatives.

e (come) present form is e-nəwa and the impolite imperative is waren.the root ya 'go' present form is ya-nəwa and paləyən is the impolite imperative form. Some examples for impolite imperative suffixes -pan and -piyə are as follows,

Class 1>

$\begin{array}{lll}\text { bala 'look' } & \text { balə-pan } & \text { balə-piyə } \\ \text { kapə 'cut' } & \text { kapə-pan } & \text { kapəpiyə }\end{array}$

class 2

The ending vowel $-\mathrm{I}$ of the verb changes to -ə before taking the impolite imperative suffixes -pan and -piyə

$\begin{array}{llll}\text { Lowi 'lick' } & \text { lewə (vowel fronting } \mathrm{i} \text { ə) } & \text { lewə-pan } & \text { lewə-piyə } \\ \text { adji 'pull' } & æ \text { æə (vowel fronting } \mathrm{i} \text { >ə) } & \text { ædə-pan } & \text { æədə-piyə }\end{array}$

class 3

ka 'eat' ka-pan ka-piyə

de 'give' di-pan di-piyə

The impolite imperative suffixes -pan and -piya have plural forms too.The plural suffixes are -lla and $-\mathrm{w}$.The $-\mathrm{n}$ of suffix - pan is replaced by - lla and the suffix $-\mathrm{w}$ is directly added to the end of -piyə.

$\begin{array}{lll}\text { Look } & \text { bala-pan } & \text { bala-palla } \\ \text { Cut } & \text { kapə-pan } & \text { kappa-palla } \\ \text { Look } & \text { bala-piyə } & \text { bala-piyə-w } \\ \text { Cut } & \text { kapə-piyə } & \text { kappa-piyə-w }\end{array}$




\section{b) Permissive Mood}

It occurs in first and third persons. sinhala has three suffixes for permissive mood. They are,

-djdən -is added to any verb root.

-den - is added to the past verbal adjective only

--we-is only added to the past form of the verbs

The permissive mood's sense is let someone do something.

Root

\begin{tabular}{|c|c|c|c|c|}
\hline -djden & -djen & -we & glo & \\
\hline wrap & oto-djden & etuwo-djen & etwa-we & Let it wrap \\
\hline weat & goto-djdjen & getuwo-den & getuwa-we & Let hime weave \\
\hline pull & adi-dden & æddə-den & ædda-we & Let him pull \\
\hline
\end{tabular}

c) Hortative Mood

It expresses the suggestions. The first person plural is only the subject of hortative forms and it is marked by adding hortative suffix - mu to the verb root. the question marker de is always precedes the hortative form.All the verbs classes occur in hortative mood.

Balə 'look' baləmu 'let's look'

Kapə 'cut' kapəmu 'let's cut'

Kadə 'break' kadəmu 'let's break'

d) Optatative Mood

It is related to the imperative mood and realized in finite forms..Verbs expressing a wish (or a curse) a will or a desire with the implication of futuriry are in optative mood.Thge suffix -waa is added to the verb stem and the stem vowel is doubled to express a wish.
Bala 'look'
bala-wa 'may (you)look'
Pipe 'bloom'
pipe-wa 'may (it) bloom'
Daki 'see'
dakii-wa 'may it be seen'

For curses $-\mathrm{ia}$ is added to the stem.

kaḑənəwa 'break'

kædia

wætenəwa 'fall'

wætio

e) Conditional Mood

Sinhala conditional mood occurs in present as well as past tenses. The present conditional suffix is tot and the past suffix is -ot. The present conditional mood is formed by adding the suffix -tot to the verb root and the past conditional suffix has to be added to the past form of the verb for gatting past conditional mood.The examples are given below for present and past conditional mood.

Present conditional

$\begin{array}{llll}\text { Root } & \text { gloss } & \text { present conditional } & \text { gloss } \\ \text { Balə } & \text { look } & \text { balə- tot } & \text { if look } \\ \text { Kapə } & \text { cut } & \text { kapə-tot } & \text { if cut } \\ \text { Kadə } & \text { break } & \text { kadə- } \text { tot }_{n} & \text { if break } \\ \text { Past conditional } & & \\ \text { Root } & \text { gloss } & \text { present conditional } & \text { gloss } \\ \text { Balə } & \text { look } & \text { bæluw-ot. } & \text { If looked } \\ \text { Kapə } & \text { cut } & \text { kæpuw-ot. } & \text { If cut } \\ \text { Kadə } & \text { break } & \text { kæduw-ot. } & \text { If broke }\end{array}$




\section{f) Inferential Mood}

It always expresses futurity. The two inferential suffixes are $-\mathrm{yi}$ and -wi.The former is directly attached to the verb stem and the latter is added to the stem vowel doubling.

$\begin{array}{llr}\text { balənəwa 'look' } & \text { bala-yi } & \text { balaawi } \\ \text { adinəwa 'pull' } & \text { adi-yi } & \text { adiiwi }\end{array}$

\section{g) Exclamatory Mood}

This is used for unexpected and surprise actions and it has two suffixes -pi and -cci.

$\begin{array}{ll}\text { Balə 'look' } & \text { balə-pi 'look!' } \\ \text { Kapə 'cut' } & \text { kapə-pi 'cut!' } \\ \text { Pipe 'bloom' } & \text { pipecci 'bloom!' } \\ \text { Ride 'get pain' } & \text { ridecci 'pain!' }\end{array}$

\subsection{Verbal Nouns in Sinhala and English}

\subsubsection{Verbal Nouns in English}

A verbal noun is a noun derived from a verb. It exhibits all of the properties of ordinary nouns and none of the properties of verbs.

A verbal noun can have plural forms just like a noun. It can also occur with determiners and adjectives. In English, verbal nouns are formed with a variety of suffixes.

arrive (verb) / arrival (noun)

decide (verb) / decision (noun)

destroy (verb) / destruction (noun)

fly (verb) / flight (noun)

Her sudden arrival surprised me.

He has told his decision.

He got a flight to USA.

A verbal noun can be formed with the suffix -ing.

run (verb) / running (noun)

speak (verb) / speaking (noun).

The deliberate bowling of bouncers should be banned.

(Here the -ing form bowling is a verbal noun because it exhibits nominal properties)

\subsubsection{Verbal Nouns in Sinhala}

The verbal nouns in Sinhala are formed by adding the suffix - i :mə and -illə to the verb toot.They take number and case just like other nouns.
Balə 'look'
bæli:mə / bælillə 'looking'
Kapə 'cut'
kæpi:mə/kæpillə 'cutting'

\section{DISCUSSION}

In this research the discussion is on the verbs of Sinhala and English language comparing each category with the opposite one. Comparing the verbs of the two languages is a huge task and by doing so I could understand that these two languages share similar and dissimilar aspects.

When we see the data for the Tense of the spoken Sinhala and English language we find that both the languages has only two tenses as past and non-past. They don't have a tense for future and future is indicated using words like tomorrow, evening, next week etc.in English and heta, hawasa, labanasatiyeetc in spoken Sinhala.In both the languages. A root consist of non-past stem is used for present and future tenses and a past stem is used for past tenses. 
Some examples from Sinhala are,

Balə-nəwa 'look' (non-past tense)

Mama pothabalanawa (present tense)

Mama hetapothabalanawa.(future tense)

In English,

'Look' (non-past)

I look at the book (present tense)

I look at the book tomorrow (past tense)

Though some one can argue that English has three tense like present, future and past according to many of the linguistics English has only two tense as present or non- past and past. It is incorrect to say

'I will look at the book.' Is a future tense because according to linguists because it has the helping verb (modal verb) 'will'. So, the example is not a separate tense but an aspect of the present tense.

In spoken Sinhala most of the present tense verbs ends with '-nava' tense as well with a future indicating word.

When making the past tense of the verbs both the languages follow a complex set of rules. We can find only a few no of verbs of the same pattern and all the others fall into different other categories which we have to study separately and keep in mind. Those which have a pattern are identified as regular verbs and the rest are identified as irregular verbs. There is no one correct rule for making them past and because of this reason it will be a hindrance for learning the two languages.

In English,

\section{Non-past Tense}

Dance

\section{Past tense}

Swim danced

Teach

Lay

swam
taught
laid

All these verb have different past tense verbs and in the data analysis all these have been further discussed. The first example is a regular past tense and the other examples are of irregular past tenses. All these irregular verbs have a set of verbs which shares the same features.

In Sinhala,

$\begin{array}{lc}\text { andi-nəwa 'wear' } & \text { ænda } \\ \text { Balə-nəwa 'look' } & \text { bæluwa } \\ \text { Parawe-nəwa 'wither' } & \text { parauna } \\ \text { Ya-nəwa 'go' } & \text { giaa }\end{array}$

The first three examples are regular verbs of different categories and the fourth one is an example for irregular past tense Sinhala verb.

Accordingly we find similarities of the tenses of the two languages and it does help the learner in a way to identify the similar structures of the tenses of Sinhala and English language and after studying them carefully one can get a good understanding of the two languages and the study here anyway does not give a direct relation to see the two languages as one, sharing the same features.

When we see the aspect of the two languages, we find English has four aspects: simple, progressive, perfect, and perfect-progressive whereas Sinhala has no aspect. Aspect is defined as a grammatical category that expresses how an action, event or state denoted by a verb extends over time and aspect conveys other temporal information, such as duration, completion, or frequency, as it relates to the time of action. Aspect can be said to describe the texture of the time in which a situation occurs, such 
as a single point of time, a continuous range of time, a sequence of discrete points in time, etc., whereas tense indicates its location in time.

English has four aspects: simple, progressive, perfect, and perfect-progressive.

The simple aspect is the aspect of the simple present and simple past tenses. The simple aspect expresses single actions, habits, and routines.

She goes home.

He went to Kandy.

The progressive aspect expresses incomplete or ongoing actions.

I am writing a letter.

The use of the progressive aspect in the above example indicates that I started writing a letter in the past and I am still writing the letter in the present and presumably the future.

The perfect aspect expresses the consequences resulting from a previous action or state.

I have written a letter.

The use of the perfect aspect in 'I have written a letter' focuses on the end result of my writing the letter as opposed to the process writing the letter.

The perfect-progressive aspect expresses incomplete or ongoing actions or states that the thing began in the past and continue to a specific time.

For example, the use of the perfect-progressive aspect in I had been reading the book indicates that I started reading the book in the past and continued to read the book until a specific point in time at which I stopped reading the book.

Present participles, or -ing forms, are formed by adding the suffix -ing to the base form of a verb. For example, the present participles of eat and read are eating and reading. Past participles, or -en forms, are formed

- Identically to the -ed past tense,

- By adding the suffix -en to the base form, or

- With a stem change- the past participles of study, take, and begin are studied, taken, and begun.

Sinhala has no inflection.

The mood of the two languages are different in the sense English has three moods: indicative, subjunctive, and imperative and there are seven moods in Sinhala. They are, imperative mood, permissive mood, hortative mood, optative mood, conditional mood, inferential mood and exclamatory mood.

The most common moods in English include the following:

The three major modalities are indicative, which mere indicates that something occurs, imperative, which demands that something occurs, and subjunctive, which suggests that something might occur, usually also implying that it doesn't occur.

Indicative John eats

Imperative Eat!

Subjunctive I would eat, Were I to eat

The indicative (indicating a state of factuality and reality): "A cat sits on the stove." Most sentences in English are in the indicative mood. It simply states a fact of some sort, or describes what happens, or gives details about reality.

The imperative (indicating a state of command): "Give me back my money." One marker of the imperative is that frequently the subject does not appear in the sentence, but is only implied: "(You) Give me back my money." 
Another, mood is the subjunctive mood (indicating a hypothetical state, a state contrary to reality, such as a wish, a desire, or an imaginary situation). It is harder to explain the subjunctive. Five hundred years ago, English had a highly developed subjunctive mood. However, after the fourteenth century, speakers of English used the subjunctive less frequently. Today, the mood has practically vanished; modern speakers tend to use the conditional forms of "could" and "would" to indicate statements contrary to reality. The subjunctive only survives in a few, fossilized examples, which can be confusing.

In Sinhala the moods of the verbs are identified as follows,

\section{Imperative mood}

In imperative mood only the second person is involved .It is formed by adding the imperative suffux nno to the end of the verb root.

balə+nnə =balənnə 'look'

\section{Permissive mood}

It occurs in first and third persons. sinhala has three suffixes for permissive mood. They are,

-djdən -is added to any verb root.

-den - is added to the past verbal adjective only

--we-is only added to the past form of the verbs

The permissive mood's sense is let someone do something.

\section{Hortative mood}

It expresses the suggestions. The first person plural is only the subject of hortative forms and it is marked by adding hortative suffix - mu to the verb root. the question marker de is always precedes the hortative form. All the verbs classes occur in hortative mood.

Balə 'look' baləmu 'let's look'

\section{Optatative mood}

It is related to the imperative mood and realized in finite forms..Verbs expressing a wish (or a curse) a will or a desire with the implication of futuriry are in optative mood.Thge suffix -waa is added to the verb stem and the stem vowel is doubled to express a wish.

Bala 'look' bala-wa 'may (you)look'

\section{Conditional mood}

Sinhala conditional mood occurs in present as well as past tenses. The present conditional suffix is tot and the past suffix is - ot. The present conditional mood is formed by adding the suffix - tot to the verb root and the past conditional suffix has to be added to the past form of the verb for gatting past conditional mood.

\section{Inferencial mood}

It always expresses futurity. The two inferential suffixes are -yi and -wi.The former is directly attached to the verb stem and the latter is added to the stem vowel doubling.

balənəwa 'look' bala-yi balaawi

\section{Exclamatory mood}

This is used for unexpected and surprise actions and it has two suffixes -pi and -cci.

Balə 'look'

$$
\text { balə-pi 'look!' }
$$

When we talk about the verbal nouns in Sinhala and English languages, both the languages have that feature.

English verbal nouns,

arrive (verb) / arrival (noun) 
decide (verb) / decision (noun)

destroy (verb) / destruction (noun)

fly (verb) / flight (noun)

Sinhala verbal nouns,

Balə 'look' bæli:mə / bælillə 'looking'

Kapə 'cut' kæpi:mə/kæpillə 'cutting'

\section{REFERENCES}

[1] Bauer, L. (1983). English Word-Formation. doi:10.1017/cbo9781139165846

[2] BauerLaurie,LieberRochelle andPlag Ingo,"The Oxford Reference Guide to English Morphology

[3] Coates, W. A., \&Gair, J. W. (1972). Colloquial Sinhalese Clause Structures. Language, 48(2), 463. doi: $10.2307 / 412147$

[4] Chandralal, D. (2010). Sinhala. London Oriental and African Language Library. doi:10.1075/loall.15

[5] Gair,James W. Lust Barbara,1998,Sinhala and Other South Asian Languages

[6] Gair, James W. \&Paolillo John, Sinhala

[7] Gair, J. (2006). Sinhala. Encyclopedia of Language \& Linguistics, 389-393. doi:10.1016/b0-08-044854$2 / 02242-2$

[8] Geiger Wilhelm "A grammar of the Sinhala language"

[9] Halliday M.A.K., Webster Jonathan J. "Studies in English language" - 2009

[10] Hopper, Paul J. 1999. A short course in grammar. New York: W. W. Norton \& Company. Huddleston, Rodney. 1984. Introduction to the grammar of English. Cambridge: Cambridge University Press.

[11] King, R. D. (2003). Studies in South Asian Linguistics: Sinhala and Other South Asian Languages. By James W. Gair. Edited by Barbara Lust. New York: Oxford University Press, 1998. 368 pp. $\$ 75.00$ (cloth). The Journal of Asian Studies, 62(02), 656-657. doi:10.2307/3096308

[12] Paula Rodríguez-Puente, Teresa Fanego, Evelyn Gandón-Chapela,, 2014, Current Research in Applied Linguistics: Issues on Language and cognition

[13] .Karunathilake W.S "An introduction to spoken sinhala"

[14] Premaraathne, Ashoka, The Present Tense Form in medieval Sinhalese. (Sinhala). Vagvidya 7. 9ed.) KadurugamuweNagita, D.M Wickramasinghe. Kelaniya; Department of Linguistics, University of Kelaniya.

[15] Wijerathna,W.M. "Auxiliary verbs in Sinhala" In Journal of Faculty of Humanities, Vol. iii. Eds. Gamini Dela Bandara, Ven. Induragare Dhammaratana Thero, Maithree Wickramasinghe, Lakshman Seneviratne. Kelaniya,Faculty of Humanities,University of Kelaniya. 2000/2001. pp. 055-072 (In Sinhala).

[16] http://www.historyworld.net/wrldhis/PlainTextHistories.asp?historyid=ab13

[17] http://www.thesundayleader.lk/2010/05/09/sri-lankan-english-the-state-of-the-debate/

[18] http://homes.chass.utoronto.ca/ cpercy/courses/eng6365-saunders.htm

\section{AUTHOR'S BIOGRAPHY}

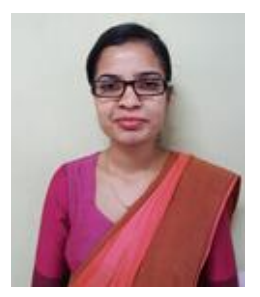

A.B.I.K.Premasiri, Lecturer in English in SLIATE, Kandy, BA (General), MA (Linguistics), MA (TESL)

Citation: A.B.I.K.Premasiri. "A Comprehensive Study on Sinhala and English Verbs". International Journal on Studies in English Language and Literature (IJSELL), vol 6, no.9, September 2018, pp. 43-57. doi:http://dx.doi.org/10.20431/2347-3134.0609006.

Copyright: (0) 2018 Authors. This is an open-access article distributed under the terms of the Creative Commons Attribution License, which permits unrestricted use, distribution, and reproduction in any medium, provided the original author and source are credited. 